World Lumen Congress 2021 | May 26-30, 2021 |

Iasi, Romania

\title{
E-learning: Introducing Computer Use in Mathematics Lessons in Primary Education
}

\author{
Daniela Alice LUTA (MANOLESCU), Adrian IOANA, \\ Bianca Cezarina ENE, Ionela Daniela JUGĂNARU, Daniela \\ TUFEANU
}

https://doi.org/10.18662/wlc2021/37

How to cite: Luta (Manolescu), D. A., Ioana, A., Ene, B. E., Jugănaru, I. D., \& Tufeanu, D. (2021). E-learning: Introducing Computer Use in Mathematics Lessons in Primary Education. In A. Sandu (vol. ed.), Lumen Proceedings: Vol. 17 World Lumen Congress 2021 (pp. 379-386). Iasi, Romania: LUMEN Publishing House. https://doi.org/10.18662/wlc2021/37 


\title{
E-learning: Introducing Computer Use in Mathematics Lessons in Primary Education
}

\author{
Daniela Alice LUTA (MANOLESCU) ${ }^{1}$, Adrian IOANA², Bianca Cezarina \\ ENE $^{3}$, Ionela Daniela JUGĂNARU ${ }^{4}$, Daniela TUFEANU 5
}

\begin{abstract}
The aim of this paper is to identify and analyze the role that the use of the computer has in stimulating the logical thinking of young schoolchildren. Through this, the purpose of the activity of solving operations with natural numbers, is to develop logical thinking, properly combining intuitive elements with abstract ones. Solving arithmetic problems, we can activate young students in the formation of skills and abilities to analyze the given situation, to intuit and discover the way to get what is required in the mathematical problem. This paper aims to prove that, if both traditional methods and computer-based teaching methods are used in the instructive-educational process, then school performance will register a significant increase in terms of quantity and quality. This experimental study started from the premise that solving arithmetic problems with the help of computer, using e-learning platforms is an important activity in the mathematics lesson in primary school through which we stimulate young students' logical thinking.
\end{abstract}

Keywords: Computer; logical thinking; mathematics; education.

\section{Introduction}

The introduction of the computer in school and its use in instruction and self-instruction has become, in recent years, a constant concern of practitioners and theorists. This is a natural consequence of the development of information technology and the transformation of the computer into a very useful working tool in the most diverse sectors of activity (Marcu\& Marinescu, 2002; Manolescu, 2004).

Education must prepare children for the accelerated pace of change in the society in which we live, create skills and abilities to adapt and, moreover, the training process itself must adapt to new conditions. The year of 2020 has completely changed the education system, as the pandemic has forced most schools to close their doors and hold all classes online. In this context, this paper aims at

\footnotetext{
1 PhD Student, University Politehnica of Bucharest, Romania. E-mail: a alice13@yahoo.com

2 Prof. Univ. PhD, University Politehnica of Bucharest, Romania. E-mail: advioana@gmail.com

${ }^{3}$ PhD Student University Politehnica of Bucharest, Romania. E-mail: biancaene80@gmail.com

${ }^{4} \mathrm{PhD}$ Student University Politehnica of Bucharest, Romania. E-mail: juganaru dana@yahoo.com

${ }^{5}$ PhD Student, University Politehnica of Bucharest, Romania. E-mail: dana.tufeanu@gmail.com
} 
testing whether mathematics classes can benefit from the use of computers.

Among the educational problems identified by teachers, which could be associated with the use of the computer theme in education are the overloaded curriculum, traditionalism and the too theoretical nature of the information transmitted. Nowadays, the computer is, indisputably, a beneficial means of didactic training. We can say that it is a revolutionary instructive means, with an impact on the educational process as it has not existed since the appearance of textbooks. Teachers themselves must master the methodology of using the computer. Regardless of their specialty in the educational process or their position, teachers must understand that this tool will transform teaching technologies(Constantin et al, 2005; Dobre, 2010).

The following advantages of using a computer in teaching are recognized by literature: stimulating learning ability, strengthening the ability to scientifically investigate, strengthening children's motivation, cultivating logical thinking, memory and imagination, the presence of a competitive climate.

\section{Problem Statement}

This experimental study aims at proving that, when both traditional methods and computer-based teaching methods are used in the instructiveeducational process, school performance registers a significant increase in terms of quantity and quality. This research started with the premise that solving arithmetic problems with the help of computer and using e-learning platforms (such as Kinderpedia) is an important activity in the mathematics lesson in primary school, through which we stimulate logical thinking.

This study seeks a significant positive change in students' attitudes towards mathematics when the teacher uses technology in teaching. The direct hypothesis is defined as follows: there is a significant difference in the attitude towards mathematics observed before and after the use of technology in teaching. The null hypothesis is formulated as follows: there is no significant difference in the attitude towards mathematics observed before and after the use of technology in teaching this discipline. (Adrian. I et. al 2020a; b) However, using the computer at random, without a precise purpose, at an inappropriate time during the activity can lead to boredom, monotony, inefficiency and failure to achieve the proposed objectives. On the other hand, excessive use can lead to impaired ability to calculate, verbalize, and investigate reality. In order to get proper results and a definite conclusion, the computer must be used at opportune times only.

\section{Objectives and the Hypotheses of the Research}

Based on the research hypothesis, this study sets out to achieve objectives such as enriching the content of activities used in solving arithmetic problems, by creating new approaches, emphasizing the psycho-pedagogical aspects of this activity, through development of logical thinking of small schoolchildren, highlighting the role of different methods of solving arithmetic problems in the formation of intellectual skills(Adrian et al., 2018). 
The main objective of our research is to introduce the use of computers in the course activities and applications for mathematics classes, since the primary level of education.

Thus, the authors aim to achieve the following goals through their own contributions in order to achieve this main objective:

- Attracting the subjects of the educational system to the intensive and efficient use of computers in educational processes in general and for mathematics classes in particular.

- Increasing efficiency and the degree of assimilation in the process of knowledge and learning.

Another objective and own contribution of the authors of this article within the scientific research carried out is the conception, elaboration and implementation of a new concept specific to the educational systems, namely the concept 3e: eknowledge; e-learning; e-recapitulation.

The significance and international importance of this article and implicitly of the contributions of the authors in the field lies in the dissemination of the high level and efficiency of the Romanian school of informatics and computers.

It can be stated that the method of learning by using the computer in mathematics classes in primary school has a beneficial role in the formation of computer skills. It is observed that the difference is relatively small, this representing a confirmation of the hypothesis. The starting hypothesis was: if learning activities are introduced by using the computer so that all students participate actively in math lessons, then they will form computational skills much easier.

\section{Research Methods}

In order to obtain the expected results, the research methods used are also the most accessible methods in the activity of young school students: observation, conversation, analysis of the activity products, test method and pedagogical experiment using Kinderpedia platform. By using the observation method, data and findings were periodically recorded and filed, as they were presented in the lessons. In the didactic projects, the operational objectives involved in the treated subject were established according to the new requirements. After each lesson, results were recorded according to how the children reacted, what new behavioral traits appeared. Moments in the lesson, the efficiency of the procedures used, the method that contributes more to student engagement, the development of flexibility and creativity of thinking, common mistakes, negative manifestations (inattention, indiscipline) were all closely monitored and the degree of success was established for each one of them. In order for the material obtained through observation to be of real use, it was necessary for the students to be followed in different situations and conditions. Observation grids are established, where the study of the instructive-educational process, based on them, exceeds the global follow-up of the phenomenon within the current observation. In addition to the analysis of some 
moments of the lesson, attention was placed on the dynamics of the dialogue with the class, the relations between the teacher and the students.

Located at the verbal level, this essential volume of interactions in the lesson, the exchange and dynamics of verbal messages provide a good approximation for opening the dialogue with students, and the direct consequences are:

- detaching the mechanism of regulation and adjustment of the students' participation in the lesson;

- checking the efficiency of the work style;

- categorizing the type of authority established in the classroom;

- realizing the psychological climate that brings teachers closer to students.

The method of observation is indispensable in the analysis and interpretation of the efficiency of its activity, ie it is a fundamental method that ensures direct contact with reality, with facts, but sometimes it proves insufficient due to the complexity of the phenomena.

Conversation is considered an auxiliary method and it is necessary that its results be compared with those obtained by other methods. The individual conversations organized with the students revealed their opinions about each procedure as well as the difficulties encountered in acquiring or applying the knowledge.

The products of the students' activity were systematically and continuously analyzed, in an attempt to find explanations for some behavioral manifestations, to make ameliorating decisions that would lead the student to an appropriate attitude.

The pedagogical experiment implies the creation of a new situation for the introduction of some modifications in the development of the educational action so that, based on the registered results, the validity of the interventions that were applied can be appreciated. The changes that are introduced in the development of the researched educational phenomenon constitute independent variables, and the changes that occurred as a result of the interventions deliberately introduced, constitute dependent variables, these to be measured and explained.

\section{Results and Discussion}

Prior to March 11, 2020, a lesson was generally conducted as follows: the teacher entered the classroom, attended, checked homework, and then moved on to blackboard to introduce new concepts or practice old ones. During the experiment, respectively, after March 11, in preparatory class A, the use of blackboard and chalk was removed, using only the computer. As the new approach (having no other alternatives) was very well received by the students, by the end of the school year all math lessons were held in this way. Only the computer was used.

Kinderpedia is a cloud, multi-language and multi-currency platform, securely hosted on Amazon servers, which works as a native application on Android and iOS and is also accessible from any browser. In the context of declaring a state of emergency and closed schools, Kinderpedia came to meet families and teachers concerned about the discontinuity of schoolwork with a video teaching remote 
module. The communication and management application for kindergartens and schools has integrated Zoom functionalities and thus allows users to create video conferences for timetable subjects and invite children directly into the application.

The experimental study was carried out in the school year 2019-2020 comprising three stages: the initial stage, the experimental stage and the evaluation stage.

The initial stage (before the pandemic) was to establish the level existing at the time the experiment was initiated (before March 11, 2020). Following the application of an initial test, a pedagogical test of knowledge, a table was made with the results obtained and it was found that the students in preparatory class within normal ranges of intellectual development. In the students' initial evaluation it was considered to give some appreciations (rewards: smiling faces, stamps, medals, etc.), these being corresponding to the elaborated performance descriptors (Figure 1).

\section{Results of initial evaluation}

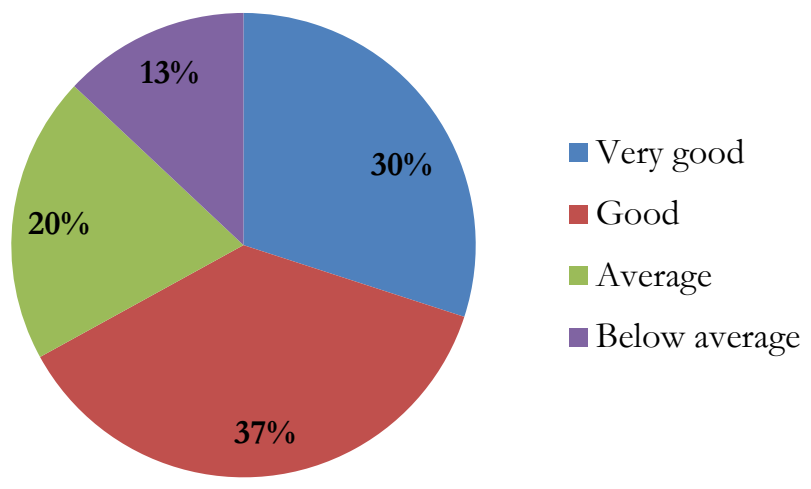

Fig. 1. Results of initial evaluation

The experimental stage involved the introduction of the computer in solving exercises with operations involving natural numbers in the $0-31$ concentric, and had in view the rigorous control of the situation. Exerciseswere solved using the Kinderpedia application and Liveworksheets, in order to verify the degree of formation of computational skills, to establish the values of the dependent variable and to adopt some ameliorating measures.

Following the results of aforementioned exercises, it was found: 12 children obtained very good grades, 14 children obtained good grades, 3 children obtained average grades and one was below average. Percentage, very good $40 \%$, good $47 \%$, average $10 \%$ and below average $3 \%$. It was found after using only the computer during this period that on the one hand there was an improvement in school results, but also a more active and enthusiastic participation of students in the class, because they were offered immediate feedback of the answers given in during the test. 


\section{Results of experimental stage}

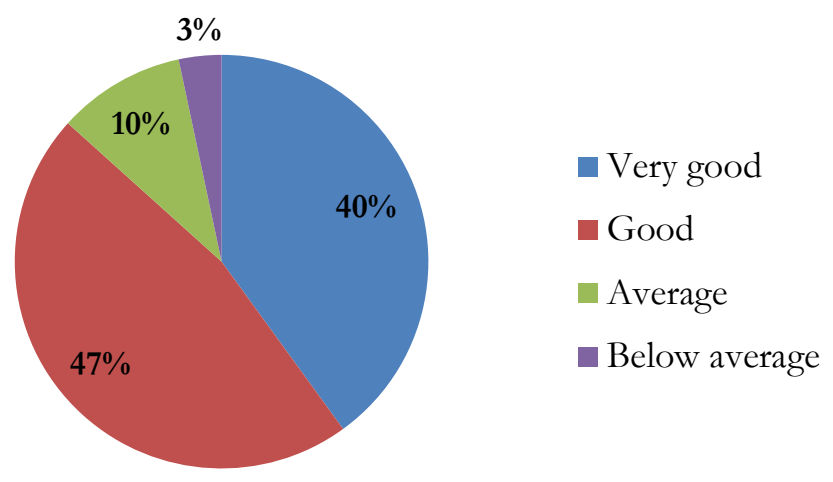

Fig. 2. Results of second evaluation (experimental stage)

The evaluation stage consisted in analyzing the two periods - the initial stage and the experimental stage for the following purposes:

- Revealing the evolution of students following the exclusive use of the computer;

- Comparing the final results and data with the starting ones;

-Establishing the relevance of the differences between the obtained results;

-Establishing the efficiency of the new way of working.

Table 1. Results obtained in the evaluation stage

\begin{tabular}{lc|cccc}
\hline \multirow{2}{*}{ Stage } & \multirow{2}{*}{$\begin{array}{c}\text { Number of } \\
\text { students }\end{array}$} & Very good & Good & Average & $\begin{array}{c}\text { Below } \\
\text { average }\end{array}$ \\
\cline { 3 - 6 } & 30 & $9(30 \%)$ & $11(37 \%)$ & $6(20 \%)$ & $4(13 \%)$ \\
\hline Initial & 30 & $12(40 \%)$ & $14(47 \%)$ & $3(10 \%)$ & $1(3 \%)$ \\
\hline
\end{tabular}

The analysis of the results obtained following the scientific research carried out by the authors of the article highlighted the following aspects:

- The share of the "Very Good" category increased following theexperiment, from $30 \%$ to $47 \%$. This significant increase proved the efficiency of the experiment performed.

- Significant but beneficial decreases were found in the "Average" category (from 20\% to 10\%) and in the "Below average" category (from 13\% to 3\%). These decreases have proved the achievement of the purpose proposed by the scientific research carried out, that of translating a large part of the "Average" and "Below average" categories into the "Very Good" and "Good" categories. This translation was 20\% (10\% from the "Average" category and also 10\% from the "Below average" category.

The participants in the scientific research carried out were on the one hand 
the authors of the article (as sources of information as teachers); and on the other hand the subjects of the research experiment, pupils and students from different educational levels.

The selection criteria for the subjects approached in the experiment were: belonging to different categories of initial training (for the relevance of the experiment); own agreement for participation in the experiment and voluntary participation, for the veracity of the experiment.

In order to ensure the research ethics, the participants gave their informed consent to participate in the study (they were informed about the possibility of withdrawal, without other consequences on their status).

The experiment performed, as a scientific method, was based on the type of pre-experimental project. Thus, only one group of participants was analyzed, without a control group. In future research, the authors aim to expand the experiment through quasi-experimental projects and experimental projects.

\section{Conclusions}

The evident conclusion reached through this experiment is that using the computer in math classes in primary school as a complement to individual and frontal activities, ensures active participation of students in their own training, as well as motivation for learning through successes and engaging students in performing different teaching tasks as a degree of difficulty. Also, learning using computational techniques determines a continuous fund of pleasure, satisfaction, the formation of intellectual work skills, the stimulation of self-confidence and the accessibility of basic mathematical notions for all students. This research confirmed that the combination of frontal activity with individual and group work, using computer-based learning techniques, increases the efficiency of the teaching process. The efficiency of cooperative learning does not mean that this method excludes the use of other methods specific to learning activities, but stimulates and favors individual activity and represents the path to the emergence of intrinsic motivation. The experimental study highlighted the level of development of logical thinking, the level of skills and computing skills acquired, the ability to solve various problems and the involvement of activation in teaching mathematics in primary school.

\section{References}

Adrian, I., Ene, B. C., Florea, B., Juganaru, D. I., Manolescu- Luta, D. A., Marcu, D. F., \& Tufeanu, D (2020a). Management Aspects Regarding Parameters for Evaluation of the Performance of Educational Systems. 36th IBIMA Conference Granada, Spain. https://ibima.org/accepted-paper/management-aspects-regarding-parameters-forevaluation-of-the-performance-of-educational-systems/

Adrian, I., Ene, B. C., Florea, B., Juganaru, D. I., Manolescu- Luta, D. A., Marcu, D. F., \& Tufeanu, D (2020b). Research Regarding Specific Management Principles Increasing the Quality of Educational Systems. 36th IBIMA Conference Granada, Spain. 
Daniela Alice LUTA (MANOLESCU) et al.| Lumen Proceedings 17 | WLC 2021

https://ibima.org/accepted-paper/research-regarding-specific-managementprinciples-increasing-the-quality-of-educational-systems/

Adrian, I., Semenescu, A., Tufeanu, D. (2018). Management Criteria and Principles Applicable in Education and Scientific Research, Advanced Engineering., Conference of Advances In Engineering \& Management, Drobeta Turnu Severin. https://doi.org/10.4028/www.scientific.net/AEF.33

Constantin, R., Dumitrescu, L., Gavrilă, R. M, Sarivan, L., Sarivan, S., \& Stoicescu, D. (2005). Predarea interactivă centrată pe elev (modul pentru dezvoltare, a profesională a personalului didactic) [Student-centered interactive teaching (professional development, teaching staff)]. Editura Educația 2000+.

Dobre, I. (2010). Studiu critic al actualelor sisteme de e-learning [Critical study of current elearning systems]. Academia Română, Institutul de Cercetări pentru Inteligență Artificială, Bucureşti. https://www.scribd.com/document/68626294/e-Learning

Liveworksheets.com. https://www.liveworksheets.com

Manolescu, M. (2004). Curriculum pentru învățământul primar şi preşcolar. Teorie și practică [Curriculum for primary and pre-school education. Theory and practice]. Editura Credis.

Marcu, V., \& Marinescu, M. (2002). Implementarea tehnologiilor în educație. [Implementation of technologies in education]. Editura Universitatea Oradea. 